\title{
The Examination of the Influence of Transformational Leadership over Commitment to Service Quality: A Case of Hospitals of Sindh, Pakistan
}

\author{
Munwar Hussain Pahi ${ }^{1} \&$ Kamal Ab. Hamid ${ }^{1}$ \\ ${ }^{1}$ School of Business Management, University Utara Malaysia, Malaysia \\ Correspondence: Munwar Hussain Pahi, School of Business Management, University Utara Malaysia. Malaysia. \\ Tel: 60-112-779-5520. E-mail: hussainpahi@gmail.com
}

Received: July 1, 2015 Accepted: August 17, 2015 Online Published: September 21, 2015

doi:10.5539/ass.v11n26p183 URL: http://dx.doi.org/10.5539/ass.v11n26p183

\begin{abstract}
Majority of the main stream literature provides the evidence that commitment to service quality (CSQ) is vital in ensuring excellent service quality. Past studies on the commitment to service quality are also limited only to the management level of analysis in service industries so the main focus of this study is to examine the relationship between transformational leadership style and commitment to service quality among the medical staff of Sindh Pakistan. A total number of 317 questionnaires were received through survey questionnaire from medical staff in four cities of Sindh, Pakistan. The data was analyzed using SmartPLS 2.0. The findings of this study indicate a significantly positive relationship between transformational leadership style and commitment to service quality. The managerial implications for the top management of hospitals are discussed. Policy makers, leaders at hospital, they motivating the staff to towards commitment to service quality. Results focused on how transformational leadership style can be used to manage commitment to service quality.
\end{abstract}

Keywords: commitment to service quality, transformational leadership, Hospitals, Pakistan

\section{Introduction}

Front line employees are interacting directly with customer and accountable for service delivery to customer and satisfaction which help to increase the performance (Parasuraman, Zeithaml, \& Berry, 1985; Hartline, Wooldridge, \& Jones, 2003). According to most of practitioners, observers and researchers (Hartline \& Ferrell, 1996; Hartline, 2000; Maxham \& McKee, 2000; Bowen \& Schneider, 1985) accept that front line committed employee with his/her job organization show the low level stress, share customer-oriented values and deliver maximum service quality. Previous research evidence that leadership style has a incredible impact on employees' behavior, containing acceptance of the organization's strategic and marketing initiatives-particularly those relating to customer service (Ahmed \& Parasuraman, 1994).

Furthermore, literature provides the evidence that commitment to service quality (CSQ) is vital in ensuring excellent service quality (Babakus, Yavas, Karatepe, \& Avci, 2003; Hartline, Maxham, \& McKee, 2000; Elmadag, Ellinger, \& Franke, 2008; Clark \& Hartline, 2009). But Past studies on the commitment to service quality are also limited only to the management level of analysis in service industries (Reeves \& Hoy, 1993; Hartline \& Ferell, 1996; Babakus et al., 2003; Hartline et al., 2000; Malhorta \& Mukherjee, 2004; Subramony, Beehr, \& Johnson, 2004; Ashill, Carruthers, \& Krisjanous, 2006; Little \& Dean, 2006; Kim, Tavitiyaman, \& Kim, 2009). All these studies have reported that when the management is committed to service quality it in turn brings about positive organizational commitment among the employees. Peccei and Rosenthal (1997) and Worsfold (1999) discovered that there is not paid much attention paid to employees' CSQ particularly when the concern is on continuous improvement in the customer expectations.

Different studies on the hospitals in Pakistan (Irfan \& Ijaz 2011; Nisa, Sadaf, \& Zahid, 2012) reported that the medical staff is not willing to provide service to customer, found low on taking responsibility and are less committed to provide service to the customers. Furthermore, past studies conducted on the hospitals in Pakistan with regards to service quality report lack of commitment of medical staff for providing excellent services (Zaidi, Mayhew, Cleland, \& Green, 2012; Akbari, Rankaduwa, \& Kiani, 2009; Afzal \& Yusuf, 2013; Saeed et al., 2013; Khan, Shaikh, Ahmed, Zafar, Tahir, \& Shaikh, 2014; Ullah, 2012; Abdullah \& Shaw, 2007; Razzak, Ahmed, 
Saleem, \& Nasrullah, 2009; Rabbani, Lalji, Abbas, Jafri, Razzak, Nabi, \& Tomson, 2011; Rabbani, Jafri, Abbas, Jahan, \& Syed, 2009; Khowaja, 2009; Saeed \& Ibrahim, 2005; Riaz, Ayaz, Wain, \& Sajid, 2012; Malik, Chaudhry, Karamat, Arif, Cheema, \& Rauf, 2010; Khan, Ahmad, Aleem, \& Hamed, 2011). Despite these studies conducted in the hospital settings in Pakistan, there has been no or lack of attention paid to CSQ which points towards an urgent need of further examination of commitment to service quality in the hospitals in Pakistan.

Achieving a good level of employees' CSQ is of great importance for each service organization (Asgari, 2014). In two separate studies (Irfan \& Ijaz, 2011; Natasha \& Sbroto, 2003) mentioned that customer contact employees do not initiate and give importance to their customers suggesting leaders to enhance the commitment of frontline employees to deliver service quality. Literature also suggests that leadership mechanism might help to overcome this situation (Waldman, 1993; Jabnoun, 2002; Natasha \& Subroto, 2003; Hartline et al., 2000; Clark et al., 2009; Hashim \& Mahmood, 2012) further suggesting that as the leaders help in envisioning the goal and they provide the resources and environment which can enhance CSQ. Particularly, Transformational leadership style has the potential to enhance CSQ (Clark et al., 2009). Hence the main objective of this study is to examine the influence of transformational leadership style over CQS in the hospitals in Sindh, Pakistan.

\section{Literature}

\subsection{Transformational Leadership and Commitment to Service Quality (CSQ)}

Several studies have demonstrated that transformational leaders are seen to lead their employees to convey high affective commitment (Clark et al., 2009; Erkutlu, 2006; Barnett et al., 2001; Liao \& Chuang, 2007). Meyer and Allen (1991) described that Affective commitment "an employee's emotional attachment to, identification with and involvement in the organization".

As the transformational leaders are charismatic in nature and they are visionary therefore research reports that when employees work under them they are more committed with their service organizations (Narimawati, 2007; McGuire \& Kennerly, 2006; Nguni et al., 2006; Emery \& Barker, 2007; Chen, 2004). The transformational leadership has been under a mainstream research theme throughout the last two decades. The empirically findings of the previous research report that transformational leadership enhances attitude and performance of employees (Lowe et al., 1996; Bass, 1999). There is sufficient evidence available in the past research that transformational leader's can greater the employees' satisfaction and commitment to their organizations (Clark et al., 2009; Barling et al., 2000; Hater \& Bass, 1988).

The employees who are following the transformational leaders that they have been developed the high sense of commitment to service to their organizations (Nguni et al.; 2006; Emery \& Barker; 2007; McGuire \& Kennerly, 2006). As findings, transformational leadership has ability to promote commitment when followers realize that commitment to service quality help their organization in competitive advantage over contenders and come across their client's satisfaction. Studies, like those published by Emery and Barker (2007); Erkutlu (2006); Barnett, et al. (2001); and Liao and Chuang (2007) support the viewpoint that transformational leadership affects the subordinates' commitment. For example, a study by Erkutlu (2006) based on a boutique hotel in Turkey, found a strong connection between transformational leadership styles and employees' commitment. Of particular importance is that the general notion of transformational leaders in enhancing employees' organizational commitment will in turn create loyalty and reduce turnover among employees (Rayton, 2006). Hence, the literature reports positive relationship between transformational leadership and commitment to service quality (Clark et al., 2009; Hashim \& Mahmood, 2012) based on which following relationship is hypothesized.

H: Transformational leadership style is positively related to commitment to service quality.

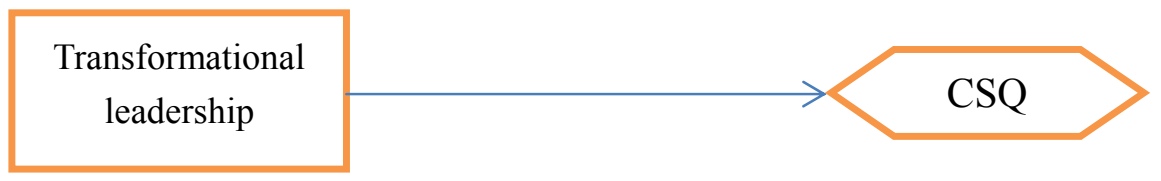

Figure 1. Theoretical framework

\section{Methodology}

\subsection{Instrumentation and Data Collection Procedure}

The multifactor leadership questionnaire (MLQ 5x-short form) from the work of (Bass, 1985) consisting of 20-items was employed to measure transformational leadership, following (Boehnke et al., 2003; Antonakis et al., 
2003). For the purpose of measuring commitment to service quality the modified version of CSQ suggested by (Clark et al., 2009) with 9-itmes was used for this study, which was originally developed by Mowday, Steers, and Porter (1979). These above measures were rated on five point scale with 5 denominating strongly agree and 1 indicating strongly disagree.

The data was collected using survey questionnaire from the medical staff of 43 hospitals of Sindh province in Pakistan. For the total population of 70,594 medical staff in the 43 hospitals in Sindh province a minimum of 382 responses were required (Krejcie \& Morgan, 1970) however to improve response rate 764 questionnaires were distributed out of which 317 useable questionnaires were received.

\section{Results}

\subsection{Demographic Profile}

In comparing the male and female respondents for this study the number of male respondent (55.8\%) was found slightly higher than female (44.2). The majority of the respondents $(55.2 \%)$ were having MBBS, whereas participating holding FPCS were (6.9\%), 3.8\% were ( $\mathrm{PhD}$ or Specialization) holders and $24.3 \%$ were having educational degree. Mostly respondents were of middle age 20 to 30 years (61.5\%) and second highest age group was 30 to 40 years with (26.8\%). In between 40 to 50 years the respondents were $(10.4 \%)$ and for 50 to 60 years there was only $(1.35 \%)$. In terms of length of service $32.2 \%$ staff were having one to five years' work experience, $31.5 \%$ had less than one year work experience, $23 \%$ had five to ten years work experience, staff with $10-15$ years' experience was $5.7 \%$ and $8 \%$ were having 15 years and more work experience.

\section{Measurement Model}

To empirically ascertain the construct validity of the model, researchers apply a 2-step Structural Equations Modeling (SEM) approach that has been recommended by Anderson and Gerbing (1988). Following Anderson and Gerbing (1988)'s approach first, researcher assessed the internal reliability convergent validity for constructs, followed by the discriminant validity of constructs results in table 1 and table 2 respectively. Following the rule of thumb.

Table 1. Result of measurement model

\begin{tabular}{|c|c|c|c|c|}
\hline latent variable & Item & Loading & AVE & CR \\
\hline \multirow[t]{11}{*}{ Transformational leadership } & TSL11 & 0.946755 & 0.61369 & 0.9253 \\
\hline & TSL13 & 0.81891 & & \\
\hline & TSL15 & 0.906717 & & \\
\hline & TSL16 & 0.892859 & & \\
\hline & TSL17 & 0.770399 & & \\
\hline & TSL2 & 0.903416 & & \\
\hline & TSL20 & 0.915564 & & \\
\hline & TSL5 & 0.842854 & & \\
\hline & TSL6 & 0.722149 & & \\
\hline & TSL8 & 0.935193 & & \\
\hline & TSL9 & 0.630554 & & \\
\hline \multirow[t]{8}{*}{ Commitment to service quality } & CSQ1 & 0.893736 & 0.72167 & 0.9657 \\
\hline & CSQ2 & 0.815849 & & \\
\hline & CSQ4 & 0.710551 & & \\
\hline & CSQ5 & 0.824417 & & \\
\hline & CSQ6 & 0.851901 & & \\
\hline & CSQ7 & 0.472963 & & \\
\hline & CSQ8 & 0.831747 & & \\
\hline & CSQ9 & 0.787 & & \\
\hline
\end{tabular}

TSL1, TSL3, TSL4, TSL7, TSL10, TSL12, TSL14, TSL18, TSL19 and CSQ3, CSQ9 were deleted because these loading are less than 0.4 following to Hulland (1999). Composite reliability $(\mathrm{CR})=$ Square of summation+square of factor loading/square of summation of the factor loadings/ summation of the square of the factors + summation of the error variances. 
Table 2. Discriminatory validity of constructs

\begin{tabular}{ccc}
\hline Latent variable & $\mathbf{1}$ & $\mathbf{2}$ \\
\hline Commitment to service quality & 0.849512 & \\
Transformational leadership & 0.693216 & 0.783383686 \\
\hline
\end{tabular}

The square root of average variance extracted while others entries represent the correlations.

Recommended values for cross loadings and composite reliability is 0.7 and above while for the average variance extracted should be above 0.5 (Bagozzi et al., 1991). Additionally, to ascertain discriminate validity of construct, the average variance shared between each construct and its measures should exceed the variance between the construct and other constructs (Fornell \& Larcker, 1981). As evidenced in Table 1, the values for average variance extracted exceeded the recommended value of 0.5 set in the previous studies (Bagozzi et al., 1991; Chi, 1998). Simararly, all factors loading have exceeded the recommended level 0.7 set in the previous studies (Bagozzi et al., 1991; Gefen et al., 2000), suggesting that the measurement model has achieved satisfactory internal reliability and convergent validity. According to (Hair et al., 2010) and Fornell and Larcker, (1981) Regarding the discriminant validity of the theatrical constructs (Table 2), the correlations for each construct is less than the square root of the average variance extracted suggesting that the measurement model has reached acceptable discriminate validity.

\section{Structure Model}

Structural model: after presenting the results of measurement model, next were the results of the structural model (Ringle et al., 2005) are presntted in Table 3 and Figure 2.

Table 3. Path coefficient and hypothesis testing

\begin{tabular}{llllll}
\hline H & Relation & Beta & SE & P value & Decision \\
\hline H1 & $\begin{array}{l}\text { Transformational leadership and commitment } \\
\text { to service quality }\end{array}$ & 0.693216 & 0.003512 & 0.00 & Supported \\
\hline
\end{tabular}

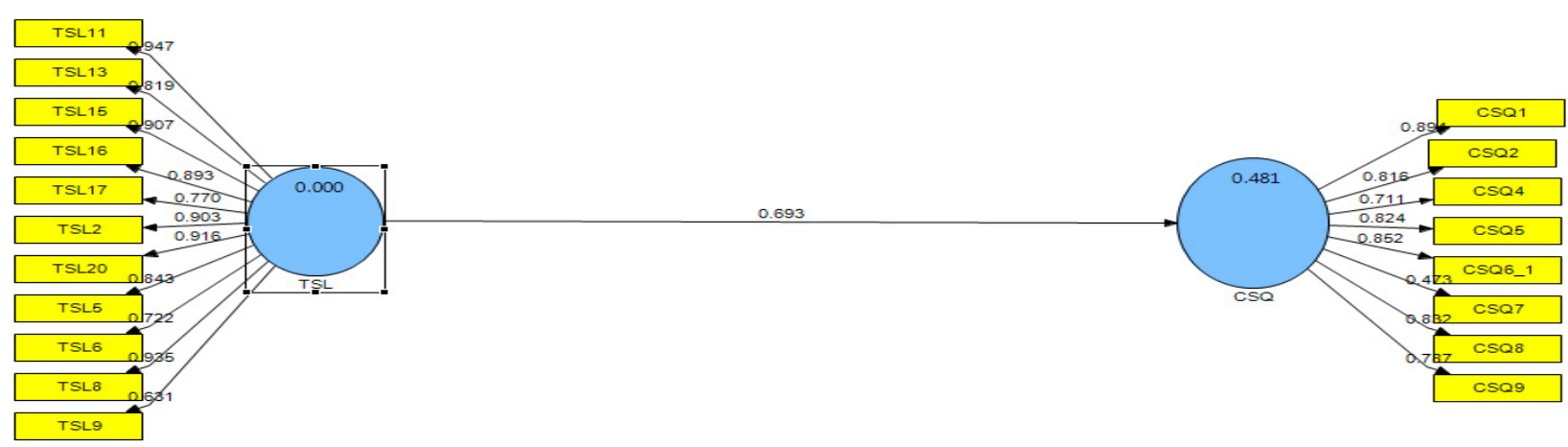

Figure 2. Result of the structural model analysis $(\mathrm{p}<0.05$; $\mathrm{p}<0.01)$

Table 3 described that relationship between transformation leadership style and CSQ. The result of relationship that significant between the transformation leadership and CSQ $(b=0.693 ; 0.00)$ similarly the result show significant positive relationship between leadership style and CSQ. Meanwhile result of figure 2, showing the hypothesis is supported. R-square reported 0.481 for leadership style. This model variables can explained $40 \%$ variance of transformational leadership.

\section{Discussion}

The influence of transformational leadership style over commitment to service quality in the medical staff of 
hospitals in Sindh, Pakistan was examined in this study. Cognitive dissonance theory Festinger's (1957) it was argued that transformational leadership influences the commitment to service quality in the medical staff of hospitals in Sindh, Pakistan. Those hospitals where leaderships tend to behave as transformational enjoy the maximum level of employees' commitment towards service quality (Clark et al., 2009; Hashim \& Mahmood, 2011). The results of this study indicate that transformational leadership style has positive relationship with commitment to service quality in the hospitals in Sindh, Pakistan. These findings are in line with the previous studies (Hashim \& Mahmood, 2011, 2012).

\section{Conclusion and Recommendation}

The findings of this study indicate that transformational leaders influence commitment to service quality of the medical staff in the hospitals in Sindh, Pakistan. The study would be helpful to managers, owners, and policy makers of the hospitals communicating them to how transformational leadership style can influence their medical staff, inspiring them, tapping their potential, promoting collaboration, encouraging and reinforcing affirmative attitude towards commitment to service quality.

Beside this, the study also has some potential limitations which require discussion, first, as the sample for this study only covers medical staff in Sindh province of Pakistan so the results cannot be generalized to all over the country or the world hence further research may be conducted at the country level to further investigate and confirm this phenomenon. Further, as the data was collected in point in time therefore a longitudinal study could further confirm these findings. Third, as the data was collected with self-reported measurement therefore there are fair chances of social desirability. Lastly, as the $\mathrm{R}^{2}$ reported for this study indicates that the transformational leadership has 0.481 percentage of variance explained in the commitment to service quality meanwhile the presence of other variables such transactional leadership, laissez-fair and role clarity may improve commitment to service quality, hence, future research may be conducted in the presence of above variables to further confirm this.

\section{References}

Abdullah, M. T., \& Shaw, J. (2007). A review of the experience of hospital autonomy in Pakistan. The International journal of health planning and management, 22(1), 45-62. http://dx.doi.org/10.1002/hpm.855

Afzal, U., \& Yusuf, A. (2013). The State of Health in Pakistan: An Overview.

Ahmed, I., \& Parasuraman, A. (1994). Environmental and positional antecedents of management commitment to service quality: A conceptual framework. In T. A. Swartz, D. E. Bowen, \& S. W. Brown (Eds.), Advances in services marketing and management (Vol. 3, pp. 69-93). Greenwich, CT: JAI. http://dx.doi.org/10.1177/ 1096348009338530

Akbari, A. H., Rankaduwa, W., \& Kiani, A. K. (2009). Demand for public health care in Pakistan. The Pakistan Development Review, 141-153.

Ali A. (2009). The Role of Leadership in Human Resource Management a Comparative Study of Specific Public and Private Sectors in Pakistan. Journal of Management and Social Sciences, 5(2), 180-194.

Anderson, J. C., \& Gerbing, D. W. (1988). Structural equation modeling in practice: A review and recommended two-step approach. Psychological bulletin, 103(3), 411. http://dx.doi.org/10.1037/0033-2909.103.3.411

Antonakis, J., Avolio, B. J., \& Sivasubramaniam, N. (2003). Context and leadership: An examination of the nine-factor full-range leadership theory using the Multifactor Leadership Questionnaire. The leadership quarterly, 14(3), 261-295. http://dx.doi.org/10.1016/S1048-9843(03)00030-4

Asgari, M. R. (2014). The effect of leadership styles on employees commitment to services quality in bank melli branches of isfahan. Kuwait chapter of the Arabian journal of business and management review, 3(12), 113.

Ashill, N. J., Carruthers, J., \& Krisjanous, J. (2006). The effect of management commitment to service quality on frontline employees' affective and performance outcomes: An empirical investigation of New Zealand public healthcare sector. Int. j. Nonprofit volunt. sect. Mark. wiley interscience, 11, 271-287.

Babakus, E., Yavas, U., Karatepe, O. M., \& Avci, T. (2003). The effect of management commitment to service quality on employees' affective and performance outcomes. Journal of the Academy of Marketing Science, 31, 272-286. http://dx.doi.org/10.1002/nvsm.281

Bagozzi, R. P., Yi, Y., \& Phillips, L. W. (1991). Assessing construct validity in organizational research. Administrative science quarterly, 421-458. http://dx.doi.org/10.2307/2393203

Barling, J., Slater, F., \& Kevin Kelloway, E. (2000). Transformational leadership and emotional intelligence: An 
exploratory study. Leadership \& Organization Development Journal, 21(3), 157-161. http://dx.doi.org/10.1108/01437730010325040

Barnett Kirn, Hi., Tavitiyaman, P., \& Kim, W. G. (2009). The effect of management to service on employee service behaviours : The mediation effect of job satisfaction. Journal of Hospitality \& Tourism Research, 33, 369-390. http://dx.doi.org/10.1177/1096348009338530

Barnett, K., McCormick, J., \& Conners, R. (2001). Transformational leadership in schools: Panacea, placebo or problem? Journal of Education Administration, 39, 24-46. http://dx.doi.org/10.1108/09578230110366892

Bass, B. M. (1998). Transformational leadership: industry, military, and educational impact. NEW Jersey: Erlbaaum.

Boehnke, K., Bontis, N., DiStefano, J. J., \& DiStefano, A. C. (2003). Transformational leadership: An examinantion of cross differences and similarities. Leadership \& Organization Development Journal, 24, 5-15. http://dx.doi.org/10.1108/01437730310457285

Bowen, D. E., \& Schneider, B. (1985). Boundarys panning role employees and the service encounter: Some guidelines for management and research. In J. A. Czepiel, M. R. Solomon, \& F. Carol (Eds.) The service encounter: Managing employee/customer interaction in service businesses (pp. 127-147). Lexington, MA: D.C. Heath. http://dx.doi.org/10.1177/109467050031005

Chaudhry, A. Q., \& Husnain, J. (2012). Impact of transactional and laissez faire leadership style on motivation. International Journal of Business and Social Science, 3(7), 258-264.

Chen, L. Y. (2004). Examining the effect of organization culture and leadership behaviours on organizational commitment, job satisfaction, and job performance at small and middle-sized firms of Taiwan. The Journal of American Academy of Business, Cambridge, 5, 232-438.

Chin, W. W. (1998). The partial least squares approach to structural equation modeling. Modern methods for business research, 295(2), 295-336. http://dx.doi.org/10.1108/S1745-3542(2012)0000008007

Clark, R. A., Hartline, M. D., \& Jones, K. C. (2009). The effects of leadership style on hotel employees' commitment to service quality. Cornell Hospitality Quarterly, 1-23. http://dx.doi.org/10.1177/19389655083 15371

Elmadag, A. B., Effinger, A. E., \& Franke, G. R. (2008). Antecedents and consequences of frontline service employee commitment to service quality. Journal of Marketing Theory and Practice, 16, 95-110. http://dx.doi.org/10.2753/MTP1069.6679160201

Emery, C. R., \& Barker, K. J. (2007). The effect of transactional and transformational leadership styles on the organisational commitment and job satisfaction on customer contact personnel. Journal of Organisational Culture, Communication and Conflict, 11, 77-90.

Erkutlu, H. (2006). The impact of transformational leadership on organisational and leadership effectiveness. Journal of Management Development, 27, 708-726. http://dx.doi.org/10.1108/02621710810883616

Festinger, L. (1957). A Theory of Cognitive Dissonance. Stanford, CA: University of Stanford Press.

Fornell, C., \& Larcker, D. F. (1981). Structural equation models with unobservable variables and measurement error: Algebra and statistics. Journal of marketing research, 382-388. http://dx.doi.org/10.2307/3150980

Gefen, D., Straub, D., \& Boudreau, M. C. (2000). Structural equation modeling and regression: Guidelines for research practice. Communications of the association for information systems, 4(1), 7.

Hair, J. F., Black, W. C., Babin, B. J., \& Anderson, R. E. (2010). Multivariate data analysis (7th ed.). Prentice hall, Upper Saddle River, New Jersey.

Hartline, M. D., Wooldridge, B. R., \& Jones, K. C. (2003). Guest Perceptions of Hotel Quality Determining Which Employee Groups Count Most. Cornell Hospitality Quarterly, 44(1), 43-52. http://dx.doi.org/10. 1016/S0010-8804(03)90045-0

Hartline, M. D., Maxham III, G., \& McKee, D. O. (2000). Corridors of influence in the dissemination of customer-oriented strategy to customer contact service employees. Journal of Marketing, 64, 35-50. http://dx.doi.org/10.1509/jmkg.64.2.35.18001

Hartline, M. D., \& Ferrell, O. C. (1996). The management of customer-contact service employees: An empirical investigation. Journal of Marketing, 60, 52-70. http://dx.doi.org/10.1177/109467050031005

Hashim, R. A., \& Mahmood, R. (2012). How do our Malaysian academic staff perceive their leader's leadership 
styles in relation to their commitment to service quality?

Hashim, R. A., \& Mahmood, R. (2011). Transformational Leadership Style and Academic Staffs' Commitment to Service Quality at Malaysian Universities.

Hulland, J. (1999). Use of partial least squares (PLS) in strategic management research: A review of four recent studies. Strategic management journal, 20(2), 195-204.

Irfan, S. M., \& Ijaz, A. (2011). Comparison of service quality between private and public hospitals: Empirical evidences from Pakistan. Journal of Quality and Technology Management, 7(1), 1-22.

Jabnoun, N. (2002). Leadership styles for quality assurance and TQM. In Proceedings of the 7th international Conference on ISO 9000 and TQM (pp. 588-593). RMIT University.

Khan, A. A., Shaikh, S., Ahmed, Z., Zafar, M., Anjum, M. U., Tahir, A., \& Shaikh, F. (2014). Quality of post graduate medical training in public and private tertiary care hospitals of Karachi. Journal of Postgraduate Medical Institute (Peshawar-Pakistan), 28(1), 245-273.

Khan, A. H., Ahmad, I., Aleem, M., \& Hamed, W. (2011). Impact of Job Satisfaction on Employee Performance: An Empirical Study of Autonomous Medical Institutions of Pakistan. International Journal of Management \& Innovation, 3(2), 261-637.

Khowaja, K. (2009). Healthcare systems and care delivery in Pakistan. Journal of Nursing Administration, 39(6), 263-265. http://dx.doi.org/10.1097/NNA.0b013e3181a96473

Krejcie, R. V., \& Morgan, D. W. (1970). Determining sample size for research activities. Educational and psychological measurement, 30(3), 607-610.

Liao, H., \& Chuang, A. (2007). Transforming - service employees and climate: A multilevel, multisource examination of transformational leadership in building long-term service relationship. Journal of Applied Psychology, 92, 1006-1019. http://dx.doi.org/10.1037/0021-9010.92.4.1006

Little, M. M., \& Dean, A. M. (2006). Links between service climate, employee commitment and employees' service quality capability. Managing Service Quality, 16, 460-476. http://dx.doi.org/10.1108/09604520 610686133

Malhorta., \& Mukherjee. (2004). The relative influence of organizational commitment and job satisfaction on service quality of customer contact employees in banking call centers. Journal of Services Marketing, 18, 162-174. http://dx.doi.org/10.1108/08876040410536477

Malik, A. K., Chaudhry, A., Karamat, A., Arif, N., Cheema, M. A., \& Rauf, A. (2010). Cigarette smoking and health care professionals at Mayo Hospital, Lahore, Pakistan. J Pak Med Assoc, 60(6), 509-512.

McGuire, E., \& Kennerly, S. M. (2006). Nurse managers as transformational and transactional leaders. Nursing Economics, 24, 179-185.

Meyer, J. P., \& Allen, C. A. (1991). A three component conceptualisation of organisational commitment. Human Resources Management Review, 1, 61. http://dx.doi.org/10.1016/1053-4822(91)90011-Z

Mowday, R., Steers, R., \& Porter, L. (1979). The measurement of organisational commitment. Journal of Vocational Behaviour, 14, 224-227.

Mukhtar, H., Saeed, A., \& Ata, G. (2013). Measuring service quality in Public Sector using SERVQUAL: A case of Punjab Dental Hospital, Lahore. Research on Humanities and Social Sciences, 3(22), 65-70.

Narimawati, U. S. E. (2007). The influence of work satisfaction, organizational commitment and turnover intention towards the performance of lecturers at West Java private higher institution institution. Journal of Applied Sciences Research, 3, 549-557.

Natasha, D., \& Subroto, B. (2003). Effects of management commitment on service quality to increase customer satisfaction of domestic airlines in Indonesia. Singapore Management Review, 25, 85-102.

Nguni, S., Sleegers, P., \& Denessen, E. (2006). Transformational and transactional leadership effects on teachers' job satisfaction, organizational commitment, and organizational citizenship behaviour in primary schools: The Tanzanian case. School Effectiveness and School Improvement, 17, 145-177. http://dx.doi.org/10.1080/ 09243450600565746

Nisa, M., Sadaf, R., \& Zahid, M. (2012). Patient satisfaction survey in an obstetric and action survey in an obstetrics and gynecology ward of a tertiary care hospital and of a tertiary care hospital and of a tertiary care hospital. 
Parasuraman, A., Zeithaml, V. A., \& Berry, L. L. (1985). A Conceptual Model of Service Quality and its Implications for Future Research. Journal of Marketing, 49, 41- 50. http://dx.doi.org/10.2307/1251430

Peccei, R., \& Rosenthal, P. (1997). The antecedents of employee commitment to customer service: Evidence from a UK service context. The International Journal of Human Resource Management, 8, 66.

Rabbani, F., Jafri, S. M. W., Abbas, F., Jahan, F., Syed, N. A., Pappas, G., \& Tomson, G. (2009). Culture and quality care perceptions in a Pakistani hospital. International Journal of Health Care Quality Assurance, 22(5), 498-513. http://dx.doi.org/10.1108/09526860910975607

Rabbani, F., Lalji, S. N., Abbas, F., Jafri, S. W., Razzak, J. A., Nabi, N., \& Tomson, G. (2011). Understanding the context of balanced scorecard implementation: a hospital-based case study in Pakistan. Implement Sci, 6(31), 1-14. http://dx.doi.org/10.1186/1748-5908-6-31

Rayton, B. A. (2006). Examining the interconnection of job satisfaction and organizational commitment: An application of the bivariate probit model. The International Journal of Human Resource Management, 17(1), 139-154. http://dx.doi.org/10.1080/09585190500366649

Razzak, J. A., Ahmed, A., Saleem, A. F., \& Nasrullah, M. (2009). Perceived need for emergency medicine training in Pakistan: a survey of medical education leadership. Emergency Medicine Australasia, 21(2), 143-146. http://dx.doi.org/10.1111/j.1742-6723.2008.01139.x.

Reeves, C., \& Hoy, F. (1993). Employee perceptions of management commitment and customer evaluations of quality service in independent firms. Journal of Small Business Management, 31(4), 52.

Riaz, Q., Ayaz, K., Wain, A. M., \& Sajid, M. (2012). Impact of HR Practices on Perceived Performance of Hospital Employees in Pakistan. Journal of Economics and Sustainable Development, 3(11), 10-15.

Ringle, C. M., Wende, S., \& Will, S. (2005). Smartpls 2.0 beta. University of hamburger. Hamburger, Germany.

Saeed, R., Ghafoor, M. O., Srwar, b., Lodhi, N., Arshad, H. M., \& Ahmad, M. (2013). Factor affecting customer satisfication in health care servicesim Pakistan, 3(5), 947-952.

Saeed, A., \& Ibrahim, H. (2005). Reasons for the Problems faced by Patients in Government Hospitals: results of a survey in a government hospital in Karachi, Pakistan. Journal of Pakistan Medical Association, 55(45).

Singh, J. (2000). Performance productivity and quality of frontline employees in service organisations. Journal of Marketing, 64(2), 15-34. http://dx.doi.org/10.1509/jmkg.64.2.15.17998

Subramony, M., Beehr, T. A., \& Johnson, C. M. (2004). Employee and customer perceptions of service quality in an Indian firm. International Association for Applied Psychology, 53, 311-327. http://dx.doi.org/10.1111/j. 1464-0597.2004.00173.x

Ullah, S. (2012). Behavioral Troubles for the Newcomer Doctors in the Public Sector Hospitals of Pakistan. Asian Journal of Health, 2(1). http://dx.doi.org/10.7828/ajoh.v2i1.115

Worsfold, P. (1999). HRM, performance, commitment and service quality in the hotel industry. International Journal of Contemporary Hospitality Management, 11, 340-348. http://dx.doi.org/10.1108/095961199 10293240

Zaidi, S., Mayhew, S. H., Cleland, J., \& Green, A. T. (2012). Context matters in NGO-government contracting for health service delivery: a case study from Pakistan. Health policy and planning, czr08. http://dx.doi.org/10.1093/heapol/czr081

\section{Copyrights}

Copyright for this article is retained by the author(s), with first publication rights granted to the journal.

This is an open-access article distributed under the terms and conditions of the Creative Commons Attribution license (http://creativecommons.org/licenses/by/3.0/). 